\title{
Om begrebet \\ statsmonopolistisk kapitalisme
}

\section{Paul Mattick}

I forbindelse med begrebet statsmonopolistisk kapitalisme er der i første omgang kun tale om en korrekt beskrivelse af de eksisterende samfundstilstande. Kapitalismen er gennemtrængt af monopoler og bestemmes i høj grad af disse. Staten som skal beskytte samfundsstrukturen er dermed den monopolistiske kapitals stat. Der er imidlertid ikke tale om en fuldstændig samfundsmæssig nyskabelse men om en tilstand, der også karakteriserede den tidligere kapitalisme, omend i mindre udpræget form. Ifølge Marx, som har givet os den bedste analyse af kapitalismen, forudsætter den kapitalistiske konkurrence selv monopolet, nemlig det kapitalistiske monopol til produktionsmidler.

\section{»Monopol« og »konkurrence«}

De antagonistiske klasseforhold, som udspringer heraf, nødvendiggør statsmagten, som samtidig repræsenterer kapitalens nationale interesser i den internationale konkurrence. En ren konkurrencekapitalisme eksisterede tidligere kun i den borgerlige økonomis fantasier og modeller. Men også her talte man om naturlige monopoler og monopolistiske priser. Selv om monopolerne ikke var underlagt markedslovmæssighederne var de dog ikke i stand til at påvirke disse lovmæssigheder væsentligt. 
Først sent, efter at hele industrigrene var monopoliseret, så selv den borgerlige $\varnothing$ konomi sig tvunget til at inddrage eksistensen af herskende ufuldstændig eller monopolistiske konkurrence i deres teorier og til at komme ind på de monopolistiske modifikationer af markedet.

Hvad der tog sig ud som en teoretisk vending for den borgerlige $\varnothing$ konomi, udgjorde i den marx'ske kapitalanalyse en fra begyndelsen iboende udviklingstendens i den kapitalistiske akkumulation. Kapitalernes konkurrence fører til deres koncentration og centralisering. Fra konkurrencen udvikler monopolet sig ligesom den monopolistiske konkurrence. Ligeledes får staten en stadig større betydning i den marx'ske teori, end hvad den borgerlige verden selv indrømmede den - ikke kun som understrykkelsesapparat men også som banebryder og beskytter af den kapitalistiske ekspansion. Der kan således ikke indvendes noget mod begrebet statsmonopolistisk kapitalisme, selv om det ikke siger mere end slet og ret kapitalisme. Man kan i denne forstand skelne mellem forskellige udviklingstrin i monopoliseringen og den statslige indvirken på økonomien.

Kapitalismens udvikling lader sig på denne måde bestemme som dens udvikling til statsmonopolistisk kapitalisme, og spørgsmålet rejser sig hvad det betyder for den $\varnothing$ jeblikkelige situation og den nærmeste fremtid. Det er her, at den særlige understregning af den nuværende kapitalismes statsmonopolistiske karakter får betydning.

Den kapitalistiske akkumulation rummer ikke blot en tendens til fremadskridende samfundsmæssig klasseadskillelse mellem arbejde og kapital, men også en tendens til tiltagende koncentration og centralisering af magten til at råde over den kapital der forøger sig selv. »En kapital slår mange ihjel «; hvad koncentrationen formidlet gennem konkurrencen ikke er i stand til at opnå, det lykkes for den bevidste centralisering gennem trust-, karteldannelser og monopolisering. Kapitalismen befinder sig således under vedvarende forandring på grundlag af de kapitalistiske udbytningsforhold.

For Marx var kapitalismens undergang allerede indbefattet i dens opkomst. De samme samfundsmæssige forhold som muliggjorde dens ekspansion bestemte samtidig dens nedgang. Kapitalens akkumulation var en proces gennemsyret af kriser. Under en udviklet kapitalismes betingelser - hvor arbejderstanden var den udslagsgivende klasse - rummede hver store krise muligheden for social revolution. Ser man imidlertid væk fra mulighederne for en revolutionær løsning på de kapitalistiske modsigelser, så fremstår den tiltagende monopolisering af den nationale $\varnothing$ konomi og den skærpede internationale monopolistiske konkurrence af de kapitalistiske udviklingstendenser - på trods af og ved hjælp af alle tilbageslag i kriseperioderne.

\section{»Monopol« og »Socialisme«}

Denne udvikling blev ofte betragtet som en forberedelse til socialismen, der fuldbyrdes objektivt. Med overgangen fra konkurrencen til monopol - de store 
kapitalenheder frembragt gennem akkumulationen, koncentrationen og centraliseringen - ændrede den kapitalistiske privatejendomsret til produktionsmidlerne sig til aktieselskabers og store koncernes kollektive ejendom, hvor ledelsen af virksomheden ikke længere faldt sammen med ejerne. For Marx var dette »ophævelse af den kapitalistiske produktionsmåde inden for den kapitalistiske produktionsmåde selv, altså en modsigelse, der ophæver sig selv, og som prima facie (umiddelbart) præsenterer sig som simpelt overgangspunkt til en ny produktionsform. Den manifesterer sig som en sådan modsigelse i sin fremtrædelse. Den skaber i visse sfærer et monopol og opfordrer dermed til statslig indblanding. Den frembringer på ny et finansielt aristokrati, en ny slags parasitter i skikkelse af projektmagere, spekulanter (Gründer) og rent nominelle direktører; et helt system af svindel og bedrag ved hjælp af selskabsstiftelse, aktieudstedelse og aktiehandel. Det er privat produktion uden den private ejendoms kontrol.« (Das Kapital, III, MEW 25, s. 454, da udg. bind 3, s. 570).

Selv om denne tilstand var udtryk for det kapitalistiske forfalds fuldbyrdelse, så tilskrev Friederich Engels det også en positiv side. Det var den planløse kapitalistiske produktions kapitulation over for det socialistiske samfunds planmæssige produktion. Efter hans opfattelse var der her tale om et »modtryk fra de vældigt udviklede produktivkræfter mod deres kapitalegenskab« og om en »tiltagende tvang til at anerkende deres samfundsmæssige natur, som tvinger kapitalistklassen selv til mere og mere at behandle dem som samfundsmæssige produktivkræfter, for så vidt dette overhovedet er muligt inden for kapitalforholdene.«

Engels er under alle omstændigheder her klar over, at »hverken forvandlingen til aktieselskaber eller selv til statsejendom opløser produktivkræfternes kapitalegenskaber.«I forbindelse med aktieselskaber er dette åbenlyst og hvad angår staten: »jo flere produktivkræfter den overtager som sin ejendom, desto mere bliver den virkelig totalkapitalist, desto flere statsborgere udbytter den. Arbejderen forbliver lønarbejder, proletar. Kapitalforholdet bliver ikke ophævet, det bliver tværtimod sat på spidsen. Men på spidsen slår det om. Statsejendommen til produktivkræfterne er ikke løsningen på konflikten, men den rummer i sig løsningsmuligheden. «I og med at den kapitalistiske produktionsmåde »har trængt forvandlingen af de store samfundsmæssiggjorte produktionsmidler over i statsejendom, viser den selv vejen til fuldendelse af denne omvæltning. « (Anti-Dühring, MEW 20, s. 260). Hvis monopoliseringen og statsligg ørelsen af $\varnothing$ konomien hos Engels stadig er en proces ledsaget af kriser, så får den hos Hilferding en rolle der udelukker kriserne, hvorved problemet om socialisme bliver til et rent politisk problem. Selv om byrderne for alle ikkekapitalistiske klasser bliver stadig tungere under den fremadskridende monopolisering, så fører denne proces dog til sidst til en kartelliseret, bevidst reguleret produktion, der begrænser den stadigt eksisterende samfundsmæssige antagonisme til fordelingen. Hvad der derudover skal gøres er den »bevidste regulering af $\varnothing$ konomien, ikke gennem og til nytte for kapitalmagnaterne, men 
gennem og til nytte for det totale samfund.« Finanskapitalens allerede samfundsmæssige funktion - forbindelsen mellem industri- og bankkapital - »letter overvindelsen af kapitalismen overordentligt. Så snart finanskapitalen har bragt de vigtigste produktionsgrene under sin kontrol, er det nok at samfundet bemægtiger sig finanskapitalen gennem sit bevidste eksekusitionsorgan - den af proletariatet erobrede stat - for derved at få rådighed over de vigtigste produktionsgrene.« (Das Finanskapital, Frankfurt 1968, s. 502).

For Hilferding havde finanskapitalen allerede fuldendt den nødvendige ekspropriation af den private kapital, således at statsliggørelsen kun satte den sidste streg under den af kapitalen selv frembragte samfundsmæssiggørelse af produktionsmidlerne. Denne tanke blev også taget op af Lenin. I sine forskellige arbejder over imperialismen beskrev han den tilstand kapitalismen havde nået ved århundredeskiftet som monopolistisk, parasitær, stagnerende og døende bort. Dette udviklingstrin var karakteriseret ved »overgangen fra den frie konkurrence til den monopolistiske kapitalisme (og gennem) udviklingen af et apparat til den samfundsmæssige regulering af produktionsprocessen og fordelingen af produkterne gennem bankerne og kapitalistorganisationer.« (Werke, bind 24, s. 459). Uden at komme nærmere ind på Lenins imperialismeteori skal det dog bemærkes, at for ham faldt imperialismen sammen med finanskapitalen og udgjorde den organisatoriske forberedelse til socialismen. Den centraliserede rådighedsmagt over den samfundsmæssige kapital gennem den monopolistiske finanskapital skulle kun overtages af den proletariske stat for at kunne bringes til at tjene samfundet.

Denne opfattelse, som går tilbage til Engels og som deles af Hilferding og Lenin (trods forskelle på andre områder), om at monopolkapitalismen på denne måde er banebryder for det socialistiske samfund, bygger på den falske antagelse, at de samfundsmæssige organisationsformer, som kommer frem med kapitalkoncentrationen, er identiske med samfundsmæssiggørelsen af produktionen. Således talte man også om den angivne rationelle og planmæssige organisation af enkeltvirksomhederne overfor den totale $\varnothing$ konomis irrationelle og planløse forløb, hvad der foranledigede Lenin til at forestille sig den socialistiske $\varnothing$ konomi som en gigantisk fabrik - ledet af staten. I virkeligheden er enkeltvirksomheden ligeså irrationel som den totale $\emptyset$ konomi, hvis man altså ikke anerkender det kapitalistiske profitmotiv som $\varnothing$ konomisk-rationelt princip for produktionen. De enkelte virksomheder ligger i lige så høj grad under for kapitalens valoriseringslove som hele samfundet, og de fungerer alene indenfor den almene eller monopolistiske konkurrences rammer - og deres organisatoriske former er bestemt herigennem.

\section{»Statskapitalisme« og »Monopolkapitalisme«}

Idet de følger profitmotivet organiserer monopolerne sig heller ikke uafhængigt. Hvis de alle anbringes under statens centrale kontrol, så kan staten kun reproducere dette nye kapitalforhold mellem sig og producenterne, hvis ikke 
disse ikke fjerner staten. Den vedvarende eksistens af såkaldte socialistiske stater har givet det praktiske bevis på, at begrebet socialisme i denne sammenhæng kun dækker over den aktuelle statskapitalisme eller »statssocialisme«. »Socialisme « kan defineres som fuldstændigt socialiseret kapitalisme; i denne forstand udgør statskapitalismen »socialismen«. Statsliggørelsen af kapitalen afslutter privatkapitalens klasseherredømme. «Samfundsmæssiggørelsen« af produktionsmidlerne er dog stadig kun en statsliggørelse af kapitalen som kapital. Af denne grund eksisterer konkurrencen stadig; den fører kapitalismens samfundsmæssige antagonismer ind i det statskapitalistiske system. Selv om den private kapitalakkumulation nu er udelukket, fortsætter udbytningen af mennesker gennem mennesker dog, fordi der såvel i produktions- som i konsumområdet eksisterer ulige fordeling.

Lønsystemet består stadig; statsbureaukratiet udgør den nye herskende klasse, hvis medlemmer »personificerer « kapitalen. Lønarbejde karakteriserer det statskapitalistiske system i lige så høj grad som det privatkapitalistiske (jvf. P.M. Marx und Keynes, Frankfurt 1971, København 1973, kap. 20, 21).

Denne statskapitalisme kan faktisk - dog kun på revolutionær måde - vokse ud af monopolkapitalismen og så at sige bringe monopoliseringen til dens logiske afslutning. Det fuldstændige monopol over produktionsmidlerne ophæver dog ikke kapitalforholdet, men befrier det for markedskonkurrencen, uden dermed at fjerne konkurrencen selv. Selv bortset fra, at denne uden videre forbliver på internationale områder, så ændrer den inden for statskapitalismen også kun sin form.

På baggrund af statens store rolle i krigs økonomierne under 1. verdenskrig antog Lenin monopolkapitalismen, gennem det dertil hørende imperialistiske imperativ, for en statsmonopolistisk kapitalisme, hvori staten udfører monopolernes ærinder. Dermed blev det næste skridt i retning af socialisme i de kapitalistiske lande frigørelsen af staten fra monopolernes interesser og anvendelsen af staten i hele befolkningens interesser. Rigtignok måtte monopolernes stat ifølge Lenin knuses, for at gøre plads for en ny proletarisk stat, der faktisk er grundlagt på en ophævelse af den kapitalistiske udbytning. Den statsmonopolistiske kapitalisme skulle vige for den socialistiske stat, uden derved at prisgive den statsligcentrale rådighedsmagt over den totale $\varnothing$ konomi.

\section{Angrebspunkter mod den »statsmonopolistiske kapitalisme« i dag}

Med ligestillelsen af statskapitalisme og socialisme som overgang til en statsløs kommunisme, der kan ses henlagt langt ud i det fjerne, så bliver kampen for socialismen til kamp mod den nuværende statsmonopolistiske kapitalisme. Denne kamp kan kun føres revolutionært, eftersom den statsmonopolistiske kapitalisme ikke frivilligt takker af. Selv om udbytningen af arbejderen fortsætter under statskapitalismen, så ødelægger denne dog det bestående borgerlige klasseherredømme. Imidlertid har de kommunistiske partier i de vestlige lande, som i dag tilsyneladende vender sig mod den statsmonopolistiske kapitalisme, 
allerede for årtier siden hørt op med at være revolutionære bevægelser. De er ikke længere parat til at tvinge deres eget program revolutionært igennem, men fører i stedet en skyggeboksning mod den statsmonopolistiske kapitalisme, for at indrette sig inden for dette system og derved at vinde indflydelse.

Dermed er ikke sagt, at disse partier er blevet utro mod deres egne mål. Hvor der viser sig lejlighed til det vil de uden tvivl fors $\varnothing$ ge at føre enhver fremtvungen anti-kapitalistisk bevægelse over i statskapitalisme. Eftersom sådanne bevægelser endnu ikke står på dagsordenen, anvender de al deres energi på at tilkæmpe sig magtpositioner indehfor det eksisterende samfund. Deres »kamp« mod den statsmonopolistiske kapitalisme forbliver således et tomt propagandaudtryk for at bringe »masserne «, som indtil nu ikke vender sig mod kapitalismen men kun mod dens »dårlige sider«, ind under sig.

Men under kapitalismen eksisterer der imidlertid kun uforenelige klasseinteresser. Derfor kan man ikke vinde de kapitalistisk indstillede samfundslag som falder som ofre for monopoliseringen for socialismen, eftersom deres særlige samfundsmæssige positioner vil blive ødelagt endnuhurtigere og grundigere her end under monopolkapitalismen. På kapitalismens grundlag kan man højest vinde dem for en politik, der lover at varetage deres særlige interesser, dvs en antisocialistisk politik. Bag parolet om kampen mod statsmonopolkapitalismen skjuler der sig således bebudelsen af en kontrarevolutionær politik, rettet mod socialismen.

Det er i hvert fald muligt at forestille sig, at det forstærkede monopolistiske tryk, som trækker proletariseringen af småborgerlige lag med sig, overbeviser en del af disse lag om, at deres sidste chance findes i statskapitalismen, som kan genåbne deres karriere, som er blokeret under monopolkapitalismen. Et blik på de »socialistiske lande« er tilstrækkeligt til at retfærdiggøre denne overbevisning. For arbejderen viser det samme blik imidlertid et andet billede. De længes ikke efter denne form for »socialisme «. De steder hvor den kommunistiske politik spiller en vis rolle, som f.eks. i Frankrig og Italien, ser de af den grund ikke viljen til en revolutionær omvæltning fra statsmonopolistisk kapitalisme til statskapitalisme i denne politik, men kun det politiske forsvar af deres direkte interesser inden for det eksisterende samfundssystem. De kommunistiske partiers funktion er her reformistisk, ikke revolutionær; de tjener dermed i sidste instans opretholdelsen af den statsmonopolistiske kapitalisme.

På baggrund af dette forhold er den tilsyneladende kamp mod den statsmonopolistiske kapitalisme kun en forlegenhedsparole. Det er længe siden at de kommunistiske partier var villige til at angribe kapitalismen selv, hverken på nationalt eller internationalt plan, hvad der viser sig i den »fredelige konkurrence « og de forretningsmæssige forbindelser mellem de forskellige samfundssystemer. På internationalt plan tjener den foregivne kamp mod den statsmonopolistiske kapitalisme den imperialistiske politiks øjeblikkelige krav. Man retter sig ikke mod den kapitalistiske imperialisme slet og ret, men kun mod den statslige im- 
perialistiske politik (som tjener monopolerne i bestemte lande), som modsiger egne nationale eller imperialistiske interesser. Gennem adskillelsen mellem kapitalisme og statsmonopolitisk kapitalisme lader alliancer såvel som fjentligheder mellem »socialistiske« og kapitalistiske lande sig retfærdiggøre, og dermed også forskellene mellem de »socialistiske« lande selv. Med andre ord dækker disses egen kapitalistiske og imperialistiske politik sig bag parolen om kampen mod den statsmonopolistiske kapitalisme, for at kunne spænde arbejderen foran.

Da der fremover - udover fordrivelsen af monopolerne - ikke behøves at blive lavet om på det eksisterende produktionssystem, må dette eksisterende system anses for tilstrækkeligt til socialismen. Deraf stammer den relative mangel på interesse med hensyn til den nuvængende kapitalismes kriselovmæssigheder. Skylden for de endnu vedhængende vanskeligheder og uretfærdigheder tilskrives staten, som har gjort monopolernes interesser til sine egne. Hvad der derfor kræves er en anden stat eller en anden regering, ikke et andet $\varnothing$ konomisk system. Også på dette punkt falder den nuværende kapitalismes og statskapitalismes ideer sammen. Statsmonopolkapitalismen bilder sig ligeledes ind at have ophævet kriselovmæssighederne gennem statslige indgreb i de økonomiske mekanismer. Eftersom denne illusion allerede har mistet en overbevisende styrke på grund af den genstridige virkelighed, så opstiller »oppositionen « mod den statsmonopolistiske kapitalisme krav om en mere vidtgående og til sidst fuldstændig statslig beherskelse af $\varnothing$ konomien, for at fjerne videre rystelser.

Staten skal ad politisk vej nå hvad det kapitalistiske marked selv ikke mere er i stand til at nå. De statslige indgreb i økonomien har faktisk tiltaget løbende. Konjunkturperioderne blev derved ført tilbage til den statslige $\varnothing$ konomiske politik og der opstod den forestilling, at kapitalismen faktisk lod sig regulere bevidst.

Dette var allerede foregrebet i socialistisk teori. Hilferding skriver f. eks. således: »når de monopolistiske sammenslutninger ophæver konkurrencen, så ophæver de også det eneste middel, hvorigennem en objektiv prislov kan virkeliggøres. Prisen hører op med at være en objektiv bestemt størrelse, og bliver et regnestykke for den, som gennem vilje og bevidsthed bestemmer den. ... Virkeligg ørelsen af den marx'ske koncentrationslære, de monopolistiske sammenslutninger, synes dermed at være ophævelsen af den marx'ske værditeori.« (Das Finanskapital, s. 313).

Det overstiger Hilferdings fatteevne, at det i den marx'ske værditeori ikke er priserne selv, men kun det almene prisniveau og dets forandringer, som er bestemt gennem værdiloven. Konkurrencen sigter mod en gennemsnitlig profitrate, der viser sig i prisernes afvigelser fra værdierne. Herunder opstår der ekstraprofitter eller monopolpriser og dette under hele den kapitalistiske udvikling, hvilket udgør en af årsagerne til den udvidede akkumulation. Gennem den fremadskridende monopolisering reducerer monopolpriserne de konkurrerende kapitalers gennemsnitsprofitrate. Det drejer sig her om profitter, som 
bliver overført fra konkurrencens sfære til monopolernes. Med konkurrencens undergang forsvinder også mulighederne for at overføre profitter fra den konkurrerende til den monopoliserede sektor i økonominen; den monopolistiske profitrate bliver til gennemsnitsprofitrate på basis af værdiloven.

Den monopolistiske økonomi ophæver ikke værdiloven, men stadfæster den gennem profitratens- og dermed akkumulationsratensfald også for den monopolistiske kapital og de dermed forbundne nødvendige statslige indgreb i økonomien. Sådanne indgreb støder imidlertid mod bestemte grænser i de kapitalistiske produktionsforhold og kan derfor kun betragtes som forbigående muligheder. Er disse muligheder udtømt, sætter de kapitalistiske kriselovmæssigheder sig på ny igennem og frembyder igen muligheden for en revolutionær overvinding af det kapitalistiske system. I denne forstand stiller den nuværende kapitalismes statsmonopolistiske karakter ikke proletariatet en anden opgave end kapitalismen i en hvilken som helst udgave, nemlig afskaffelse af kapitalforholdene gennem ophævelse af lønarbejdet i det klasseløse samfund.

Paul Mattick i 'Links'nr. 44, 1973. overs. Finn Hansson.

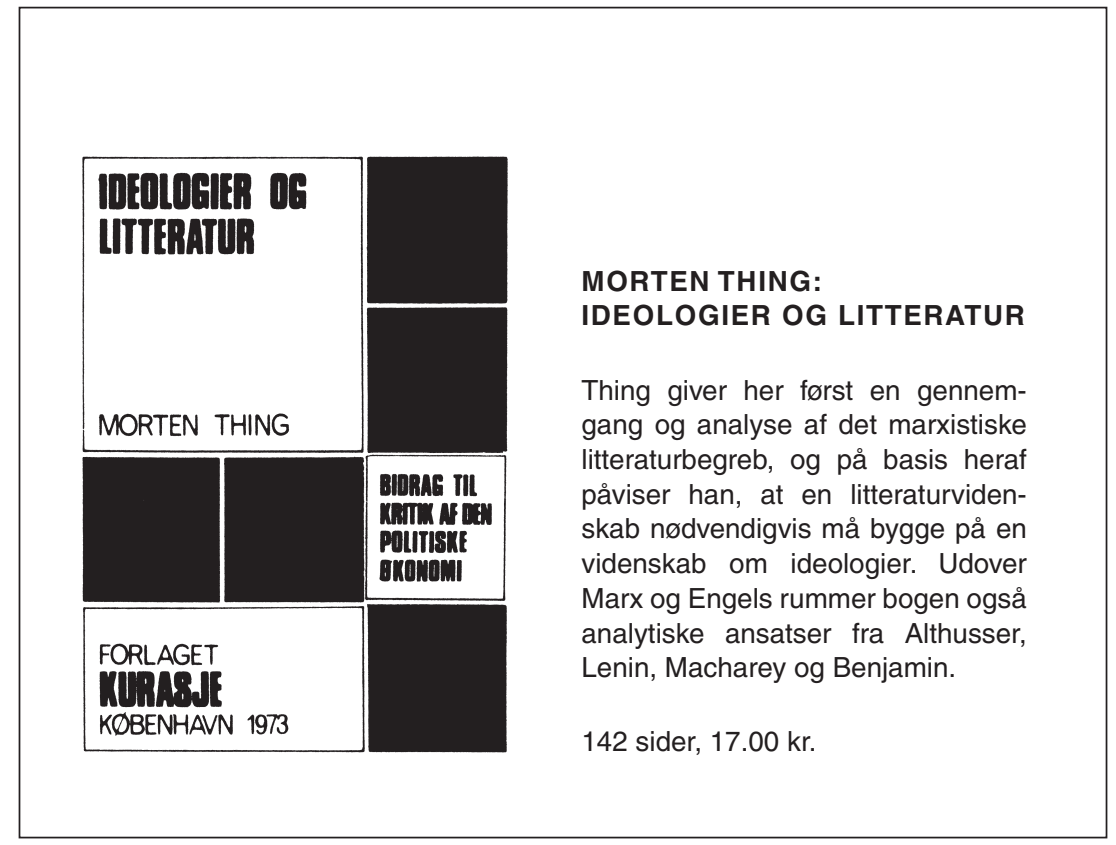

